\title{
WORLD TRENDS OF PROFESSIONAL TRAINING OF FUTURE TEACHERS IN HIGHER EDUCATION INSTITUTIONS
}

\section{Nataliia Onyshchenko ${ }^{1}$}

DOI: https://doi.org/10.30525/978-9934-26-050-6-50

In the world educational space, teacher training that meets modern European standards of professional competence is the historical mission of pedagogical universities, the implementation of which involves the implementation of appropriate organizational, substantive and methodological transformations, as stated in the Pedagogical Constitution of Europe. An important source of strategy for such reform is the study of foreign experience, which will help identify trends in the training of future teachers in higher education institutions in different countries in order to implement positive ideas of this experience in the higher education system of Ukraine.

Professional training of future teachers in foreign countries is the subject of scientific research of many Ukrainian and foreign scientists, in particular N. Avsheniuk, N. Yevtushenko, Y. Klymenko, N. Nosovets, A. Tolochyk, O. Khyzhniak, M. Azzi, D. Bosse, R. H. P. Cheung, I. Yankovych and others.

In the context of the study, the experience of training future teachers in the Netherlands is noteworthy, as Ukrainian and foreign experts note the high quality of education in the Netherland HEIs. In Netherland it is monitored the quality of education to control the country's HEIs compliance with relevant international standards. In 2002, the Netherlands adopted the Law on Higher Education, according to which all curricula offered by the Higher Education Institution must meet specially developed criteria. Only those programs that have passed the test are allowed to be used in the educational process. In the Netherlands, there are three types of HEIs: universities, polytechnics education institutions and institutes of international education. Universities specialize in teaching the humanities and conducting research. Polytechnic HEIs in the Netherlands are called hogescholen and train wide range professionals to work in various sectors of the economy. Institutes of International Education (IE) were created to teach foreign students [2].

In the Netherlands, education is divided into two periods. The first period lasts 3 years. At the end of the first period, students take an exam for a Bachelor degree. The second period allows for the next 1-2 years of study to obtain a Master degree. Many programs require a score of at least 550 on the TOEFL exam. Those who decide to study in the Netherlands are given the

\footnotetext{
${ }^{1}$ SHEI «Pereiaslav-Khmelnytskyi Hryhorii Skovoroda State Pedagogical University», Ukraine
} 
opportunity to choose one of the educational programs: national, conducted in the country language, and international - in English. In particular, there are the following educational programs: Bachelor Programs - English-language programs in some disciplines at universities (3 years) and professional institutes (4 years) with a Bachelor degree achievement; Master Programs English language programs (1-2 years) for graduates in universities, professional and international institutes with a Master degree; Advanced Master Programs - English language programs at universities (1 year) for masters with little experience in the specialty with a second master's degree; Doctorate $(\mathrm{Ph})$ Programs - scientific work on a doctoral dissertation for specialists with an international master's degree (4 years); MBA (Master of Business Administration) - a prestigious program for professionals [3].

An important feature of vocational training in universities and higher vocational education institutions of the Netherlands is the involvement of students in research. In contrast to higher vocational higher education institutions, universities in the Netherlands carry out basic research, which is provided by public funding; there is a training of researchers; introduced special requirements for entrants, which are that, entering the university, the entrant must complete high school pre-university training or have a document of completion during the year in a higher professional education institution. The peculiarity of the academic program of training in universities is that the student, along with knowledge of a particular professional field, receives a classical academic education. These trends give grounds to conclude that the uniqueness of universities in the higher education system of the country.

The leading trends in the training of specialists in the development of modern university education in the Netherlands are: compliance of professional training in universities in the Netherlands with the requirements of the European Higher Education Area; unity of educational and research activity in professional training in the conditions of universities; ensuring professional and academic mobility in universities and state financial support of university professional training. These trends take into account the processes of formation of university education, its development and meet the requirements of the European educational space [1, p. 115-120].

In the context of our study, the experience of training future teachers in Greece is important. Note that the Greek higher education system is decentralized and contains two sectors: university and vocational. The Greek Constitution gives universities full autonomy and academic freedom. Greece participates in international comparisons of the quality of language, science and mathematical literacy PISA [4, p. 142].

In Greece, there are high social standards for students: free dormitories, free meals, free medical care, including for international students. Most Greek 
free economic zones are state-owned. The competition for the Greek HEIs is very high. Enrollment is based on the results of final exams, which are taken after completing secondary education in the relevant institutions. A feature of Greek higher education is induction - the introduction of a teacher to a position under the regional In-Service Training Centers (PEK). It consists of three stages with a total duration of 100 hours, including didactic methods, education management and organization, teaching practices, assessment methods (60 hours), practical training (30 hours), and assessment and planning (10 hours). In Greece, teacher induction programs are mandatory, and teacher mentors receive an auxiliary salary.

Regarding teacher training in the Slovak Republic, it should first be noted that Slovakia has undergone a difficult path of reforms, the results of which allow us to speak about the functioning of the country's higher education system at the European level. In the context of Europeanization, the activities of higher education bodies in Slovakia can be traced in at least two directions: the first is the creation of legal bases through the adoption of regulations, the second - practical actions for their implementation and other initiatives in the educational process. In Slovakia, the law establishes a system of two main study cycles: undergraduate and postgraduate. Curricula and academic degrees of three levels are introduced in HEI: 1) Bachelor (Bc.); 2) Master (master - Mgr., Mgr.art.), Engineering (engineer - Ing., Ing.arch.), Doctor (doctor - MUDr., MVDr.); 3) doctoral (doctor - PhD, ArtD, ThLic.).

Positive changes in the education system of Slovakia are the deepening of the internationalization of higher education and science, which contributes to the expansion of multilateral cooperation of Slovak higher education institutions, increasing their competitiveness and openness, improving the quality of education and research. In Slovakia, in the context of modernizing the higher education system, teacher training curricula are adapted to the requirements of society and the labor market, which in turn affects the number of applicants for the profession; the number of graduates of higher education institutions in pedagogical specialties is increasing [6, p. 272-273]. It is worth noting the activities in the country of international, European and national rating agencies - Academic Ranking of World Universities, European University Association, European Network for Quality Assurance Agencies in Higher Education, Akademicka rankingova a ratingova agentura.

Thus, the analysis of foreign experience of professional training of future teachers allowed to identify global trends in student training at the present stage of development of higher education: multilevel model of pedagogical education; high quality of pedagogical training that meets the best world standards; the education system is decentralized; considerable attention is paid to the study of foreign languages; a systematic approach to the organization of 
professional development of teachers of general secondary education based on the restructuring and optimization of methods, forms and models of teaching through the integration of elements of practical activities into professional development curricula and the formation of continuing pedagogical education as an organically integrated, optimal and dynamic system; strengthening the independence and responsibility of students for their studies, the possibility of individualization of the curriculum, the growth of academic mobility; multiculturalism and polylingualism; multidisciplinary (acquisition of specialization in two subjects simultaneously); systematic and systematic use of innovative technologies; high level of personal-social-state orientation of the system of monitoring the quality of higher education; free access to statistics and mandatory publication of monitoring results by independent media; a small number of subjects taught (not more than 16 disciplines in one academic year); relocation of the center of professional and pedagogical training to school; growth of pedagogical practice and expansion of places of its passing; increasing the requirements for entrants both in the case of admission to pedagogical specialties and during their employment; increasing the role and importance of various professional organizations (schools of professional growth, associations, unions, centers of pedagogical skills) in the process of professional development and certification of teachers. Taking into account these features of foreign experience in the domestic system of training future teachers will contribute to the effective modernization of the higher education system of Ukraine.

\section{References:}

1. Zaiats L. I. (2014). Intehratsiia universytetiv Niderlandiv u mizhnarodne osvitnie seredovyshche. [Integration of Dutch universities into the international educational environment]. Pedahohichnyi protses: teoriia i praktyka: zb. nauk. prats. Kyiv: Edelveis, vol. 3, pp. 115-120. (in Ukrainian)

2. Zorochkina T. (2018). Pidhotovka vchyteliv pochatkovoi shkoly u rozvynenykh krainakh Yevropeiskoho Soiuzu. [Training of primary school teachers in developed countries of the European Union]. Naukovyi visnyk MNU imeni V. O. Sukhomlynskoho. Pedahohichni nauky, no. 2(61), pp. 92-97. (in Ukrainian)

3. Kolisnichenko A. (2019). Rozvytok pedahohichnoi osvity u Niderlandakh yak faktor vplyvu na riven dosiahnen zdobuvachiv osvity. [The development of teacher education in the Netherlands as a factor influencing the level of achievement of students]. Psykholoho-pedahohichni problemy suchasnoi shkoly: zb. nauk. prats, vol. 2, pp. 67-73. (in Ukrainian)

4. Korotkova Yu. M. (2008). Profesiina pidhotovka vchytelia pochatkovykh klasiv u suchasnii Hretsii: [Professional training of primary school teachers in modern Greece] dys. ... kand. ped. nauk / 13.00.01 - zahalna pedahohika ta istoriia pedahohiky. Kharkiv, 230 p. (in Ukrainian) 
5. Sapozhnykov S. V. (2011). Funktsionuvannia systemy vyshchoi osvity Hretskoi Respubliky yak krainy-chlena Chornomorskoho ekonomichnoho spivtovarystva. [Functioning of the higher education system of the Hellenic Republic as a member of the Black Sea Economic Community]. Zasoby navchalnoi ta naukovo-doslidnoi roboty, vol. 35, pp. 158-164. (in Ukrainian)

6. Zacharová J. (2013). Komparácia vývinu vysokého školstva na Slovensku v XX. a v XXI. Storočí. Prace Naukowe Akademii im. Jana Długosza w Częstochowie; Pedagogika, T. 22, pp. 259-277. 